\title{
Pengaruh Model Pembelajaran Think Talk Write Berbantuan Media Tape Recorder Terhadap Keterampilan Berbicara
}

\author{
Ni Md Lian Minarsih ${ }^{1}$, Made Putra $^{2}$ \\ ${ }^{12}$ Prodi Pendidikan Guru Sekolah Dasar, FIP \\ Universitas Pendidikan Ganesha \\ Singaraja, Indonesia \\ e-mail: made.lian.minarsih@undiksha.ac.id', madeputra@undiksha.ac.id ${ }^{2}$,
}

\begin{abstract}
Abstrak
Penelitian ini bertujuan untuk mengetahui pengaruh model pembelajaran think talk write berbantuan media tape recorder terhadap keterampilan berbicara kelas IV SD Gugus III Kecamatan Tabanan. Penelitian ini adalah penelitian eksperimen semu dengan rancangan Non-Equevalent Post Test Only Control Grup Design. Populasi penelitian ini adalah seluruh kelas IV SD Gugus III Kecamatan Tabanan sebanyak 119 siswa. Sampel diambil dengan teknik Random Sampling. Sampel dalam penelitian ini yaitu SDN 1 Denbantas sebagai kelas eksperimen sebanyak 32 siswa dan SDN 4 Dauh Peken sebagai kelas kontrol sebanyak 30 siswa. Pengumpulan data dilakukan dengan menggunakan metode nontes dalam bentuk lembar observasi. Data yang diperoleh dianalisis menggunakan uji-t. Hasil analisis data diperoleh thitung $=8,532$ sedangkan pada taraf signifikansi $5 \%$ dan $\mathrm{dk}=60$ diperoleh nilai ttabel $=2,000$ sehingga thitung $=8,532>$ ttabel $=2,000$. Hal ini berarti terdapat perbedaan yang signifikan keterampilan berbicara antara kelompok siswa yang dibelajarkan menggunakan model pembelajaran think talk write berbantuan media tape recorder dan kelompok siswa yang dibelajarkan menggunakan pembelajaran konvensional. Hasil penelitian menunjukkan nilai rata-rata kelompok eksperimen lebih dari kelompok kontrol $(\bar{x}=88,28>$ $\bar{x}=69,17)$. Jadi, terdapat pengaruh model pembelajaran think talk write berbantuan media tape recorder terhadap keterampilan berbicara kelas IV SD Gugus III Kecamatan Tabanan.
\end{abstract}

Kata-kata kunci: keterampilan berbicara, ttw, bahasa indonesia

\begin{abstract}
This study discussed the learning of think talk learning model writing assisted with tape recorder media on speaking skills in fourth grade students at SD Gugus III Kecamatan Tabanan in 2018/2019 academic year. The design of this study was quasi-experimental research with the design of Non-Equevalent Post Test Only Control Group Design. The population of this study were all fourth-grade elementary school SD Gugus III Kecamatan Tabanan consists of 119 students. The sample was taken by Random Sampling. The sample in this study was SDN 1 Denbantas as an experimental class consists of 32 students and SDN 4 Dauh Peken as a control class consists of 30 students. Data collection was done using the non-test method in the form of a collection sheet. The data obtained were analyzed using $t$-test. The results of data analysis obtained thitung $=8.532$ while at the significance level of $5 \%$ and $d k=60$ obtained a value of ttable $=2,000$ so that tcount $=8.532>t$ table $=2,000$. It means that significant discussion between groups of students who taught using the learning model think talk write assisted by tape recorder media and groups of students who taught using conventional learning. The results showed that the average value of the experimental group was more than the control group ( $\left.x^{-}=88.28>x^{-}=69.17\right)$. The speech-thinking learning model writes assisted by tape recorder media on speaking skills of fourth grade students at SD Gugus III Kecamatan Tabanan in 2018/2019 academic year.
\end{abstract}

Keywords: speaking skills, TTW, bahasa indonesia 


\section{Pendahuluan}

Pendidikan merupakan usaha sadar dan sistematis untuk mencapai taraf hidup atau untuk kemajuan lebih baik. Pembelajaran pengetahuan, keterampilan, dan kebiasaan sekelompok orang yang diturunkan dari satu generasi ke generasi berikutnya melalui pengajaran, pelatihan, atau penelitian. Sebagai usaha sadar dan terencana untuk mewujudkan suasana belajar dan proses pembelajaran untuk peserta didik secara aktif mengembangkan potensi dirinya untuk memiliki kekuatan spiritual keagamaan, pengendalian diri, kepribadian, kecerdasan, akhlak mulia, serta keterampilan yang diperlukan dirinya dan masyarakat. Pendidikan tersebut juga akan melahirkan peserta didik yang cerdas serta mempunyai kompetensi dan skill untuk dikembangkan ditengah-tengah masyarakat. Untuk mewujudkan hal ini tidak terlepas dari faktor penentu dalam keberhasilan peserta didik dalam pendidikan dan kurikulum yang digunakan.

Kurikulum 2013 adalah kurikulum yang berlaku dalam Sistem Pendidikan Indonesia. Kurikulum ini merupakan kurikulum tetap diterapkan oleh pemerintah untuk menggantikan Kurikulum 2006 (yang sering disebut sebagai Kurikulum Tingkat Satuan Pendidikan) yang telah berlaku selama kurang lebih 6 tahun. Kurikulum 2013 masuk dalam masa percobaan pada tahun 2013 dengan menjadikan beberapa sekolah menjadi sekolah rintisan. Pada tahun ajaran 2013/2014, tepatnya sekitar pertengahan tahun 2013, Kurikulum 2013 diimplementasikan secara terbatas pada sekolah perintis, yakni pada kelas I dan IV untuk tingkat Sekolah Dasar.

Kurikulum 2013 dalam konteks persekolahan lebih banyak dilaksanakan melalui pembelajaran. Pembelajaran dapat diartikan sebagai suatu upaya mengkondisikan siswa untuk dapat belajar secara efektif. Kegiatan belajar efektif terlihat bahwa ada kegiatan memilih, menetapkan, dan mengembangkan metode untuk mencapai hasil yang diinginkan dalam proses pembelajaran yang dilakukan oleh siswa dan guru. Pendidikan dalam persekolahan diharapkan siswa terlibat aktif dalam proses pembelajaran dikelas. Proses pembelajaran dikelas harus melibatkan siswa secara aktif dalam proses diskusi kelompok. Proses diskusi dikatakan akan lebih efektif apabila menggunakan media pembelajaran yang mendukung didalam proses pembelajaran. Media pembelajaran yang inovatif harus mampu mengajak siswa untuk berfikir secara ilmiah tentang pembelajaran yang disampaikan pada saat proses pembelajaran.

Pembelajaran bahasa Indonesia diarahkan untuk meningkatkan kemampuan peserta didik untuk berkomunikasi dalam bahasa Indonesia dengan baik dan benar. Hal tersebut dilakukan baik secara lisan maupun tertulis, serta menumbuhkan apresiasi terhadap hasil karya kesastraan manusia Indonesia. Standar kompetensi mata pelajaran bahasa Indonesia merupakan kualifikasi kemampuan minimal peserta didik yang menggambarkan penguasaan pengetahuan, keterampilan berbahasa, dan sikap positif terhadap bahasa dan sastra Indonesia.

Berdasarkan hasil observasi dan wawancara yang dilakukan pada hari selasa, 13 November 2018 dengan guru wali kelas dan siswa di SD Gugus III Kecamatan Tabanan menunjukkan bahwa guru belum mampu mengaplikasikan berbagai model yang bervariasi, terlebih guru menerapkan pola pembelajaran dengan mentransfer pengetahuan masih berupa hafalan kedalam kehidupan sehari-hari. Pembelajaran yang demikian menyebabkan siswa kurang aktif mengikuti pembelajaran. Berdasarkan hal tersebut telah terjadi kesenjangan antara harapan dan kenyataan dalam mata pelajaran bahasa Indonesia khususnya dalam keterampilan berbicara sebagian masih dibawah KKM. Untuk keterampilan berbicara pada muatan pelajaran bahasa Indonesia yang diperoleh dari nilai ulangan akhir semester 1 yaitu dari 119 siswa yang belum memenuhi kriteria ketuntasan minimal (KKM).

Pembelajaran yang tidak menggunakan model pembelajaran menyebabkan siswa kurang dalam diskusi kelompok. Siswa yang aktif dalam pembelajaran hanyalah siswa yang pintar, sedangkan siswa yang memiliki kemampuan kurang hanya menjadi pendengar selama proses pembelajaran berlangsung. Hal ini menyebabkan aktivitas siswa dalam proses pembelajaran rendah. Interaksi dan kerjasama siswa dalam menyelesaikan suatu permasalahan didalam kelompok umumnya masih kurang dalam artian sikap individu masih tinggi sebagian besar siswa yang jarang melakukan tukar informasi dengan teman kelompoknya, ketika diberikan tugas berkelompok dikelasnya dan tidak mau saling membantu dalam memecahkan masalah.

Apalagi dalam proses pembelajaran guru masih belum bisa mengoptimalkan berbagai media yang dapat mendukung siswa untuk belajar. Penggunaan media pembelajaran masih kurang, ini terlihat guru masih menggunakan media seadanya yang ada disekolah, sebenarnya setiap sekolah diberikan LCD proyektor untuk membantu guru mengajar dalam proses pembelajaran, tetapi sebaliknya karena dengan keterbatasan waktu dan kurang memahami 
dalam menggunakan media tersebut maka guru merasa enggan menggunakan media tersebut. Hal ini menyebabkan keterampilan berbicara siswa menjadi rendah.

Untuk mengatasi permasalahan tersebut, diperlukan inovasi dari guru untuk mengemas pembelajaran bahasa Indonesia. Inovasi yang tepat salah satu dengan menggunakan model pembelajaran yang dapat meningkatkan keterampilan berbicara pada siswa. Salah satu model pembelajaran yang cocok untuk mengatasi keterampilan berbicara siswa yaitu dengan menggunakan model pembelajaran Think Talk Write.

Menurut Aris Shoimin (2014:213) Think Talk Write adalah "suatu model pembelajaran untuk melatih keterampilan peserta didik dalam menulis". Think Talk Write ini memacu siswa untuk berfikir, berbicara, dan mencatat suatu topik tertentu. Model pembelajaran Think Talk Write dapat memberikan peluang kepada siswa untuk berinteraksi dengan sesama siswa dalam pembelajaran. Model pembelajaran Think Talk Write menekankan pada kemampuan komunikasi dan kreativitas berfikir siswa pada tahap-tahap pelaksanaannya. Dalam tahap Talk yaitu berbicara, dan mengembangkan kreativitas pada Think dan mencatat atau Write. Berdasarkan penerapan model pembelajaran Think Talk Write tersebut, maka diduga model pembelajaran Think Talk Write akan dapat memacu siswa dalam belajar sehingga hasil belajar siswa akan menjadi maksimal.

Model pembelajaran Think Talk Write pada dasarnya pembelajaran ini dibangun melalui proses berpikir, berbicara dan menulis. Strategi pembelajaran Think Talk Write dapat menumbuh kembangkan kemampuan pemecahan masalah. Alur kemajuan pembelajaran dimulai dari keterlibatan siswa dalam berfikir atau berdialog dengan dirinya sendiri setelah proses membaca, selanjutnya berbicara dan membagi ide dengan temannya sebelum menulis.

Suasana ini lebih efektif jika dilakukan dalam kelompok heterogen dengan 3-5 siswa. Dalam kelompok ini siswa diminta membaca, membuat catatan kecil, menjelaskan, mendengarkan, dan membagi ide bersama teman kemudian mengungkapkannya melalui tulisan. Aktivitas berpikir, berbicara dan menulis ini adalah salah satu bentuk aktivitas belajar mengajar yang memberikan peluang kepada siswa untuk berpartisipasi aktif. Tahapan-tahapan yang dilakukan dalam pembelajaran menggunakan tipe ini adalah berfikir (Think), berbicara (Talk), dan menulis (Write).

Menurut Suyatno (2009:66) model pembelajaran ini dimulai dengan "berpikir melalui bahan bacaan (menyimak, mengkritisi, dan alternatif solusi), hasil bacaannya dikomunikasikan dengan presentasi, diskusi, dan kemudian membuat laporan hasil presentasi".

Berdasarkan pemaparan para ahli diatas dapat disimpulkan bahwa model pembelajaran Think Talk Write adalah model pembelajaran yang lebih menekankan proses berpikir, berbicara, dan menulis, sehingga setiap pembelajaran yang dipikirkan oleh siswa dapat disampaikan dengan perencanaan yang baik dan tepat.

Adapun kelebihan model pembelajaran Think Talk Write menurut Shoimin (2014)yaitu : Mengembangkan pemecahan yang bermakna dalam memahami materi, Dengan memberikan soal open ended dapat mengembangkan keterampilan berpikir kritis dan kreatif siswa, Dengan berinteraksi dan berdiskusi dengan kelompok akan melibatkan siswa secara aktif dalam belajar, Membiasakan siswa berpikir dan berkomunikasi dengan teman, guru, bahkan dengan diri mereka sendiri.

Model Pembelajaran Think Talk Write adalah model pembelajaran yang menumbuhkan proses berfikir siswa, menanya dan menulis hasil tersebut dari proses diskusi. Model Think Talk Write berbantuan media Tape Recorder dapat meningkatkan daya ingat dan membuat siswa lebih bersemangat dalam meningikuti proses pembelajaran di kelas.

Materi rekaman audiotape adalah cara ekonomis untuk menyimpan isi pelajaran atau jenis informasi tertentu. Rekaman dapat disiapkan untuk sekelompok siswa, dan sekarang ini sudah lumrah rekaman sudah dipersiapkan untuk penggunaan perorangan. Sudjana \& Rival (1991:130) mengemukakan hubungan media audio dengan pengembangan keterampilan yang berkaitan dengan aspek-aspek keterampilan mendengarkan. Keterampilan yang dapat dicapai dengan menggunakan media audio meliputi: 1. Pemusatan perhatian dan mempertahankan perhatian. Misalnya, siswa mengidentifikasi kejadian tertentu dari rekaman yang didengarnya. 2. Mengikuti pengarahan. Misalnya, sambil mendengarkan pernyataan atau kalimat singkat, siswa menandai salah satu pilihan pernyataan yang mengandung arti yang sama. 3. Melatih daya analisis. Misalnya, siswa menentukan urut-urutan kejadian atau suatu peristiwa, atau menentukan ungkapan mana yang menjadi sebab dan yang mana akibat dari pernyataanpernyataan atau kalimat-kalimat rekaman yang didengarnya. 4. Menentukan arti dari konteks. Misalnya, siswa mendengarkan pernyataan yang belum lengkap sambil berusaha menyempurnakannya dengan memilih kata yang disiapkan itu berbunyi sangat mirip dan hanya 
dapat dibedakan apabila sudah dalam konteks kalimat. 5. Memilah-milah informasi atau gagasan yang relevan. Misalnya, rekaman yang didengarkan mengandung dua sisi informasi yang berbeda dan siswa mengelompokkan informasi ke dalam dua kelompok itu. 6 . Merangkum, mengemukakan kembali informasi. Misalnya, setelah mendengarkan rekaman suatu peristiwa atau cerita, siswa diminta untuk mengungkapkan kembali dengan kalimatkalimat mereka sendiri.

Adapun kelebihan dari tape recorder menurut Sudjana \& Rival (1991) adalah sebagai berikut: 1 . Radio tape (tape recorder) telah menjadi peralatan yang sangat lumrah dalam rumah tangga, sekolah, mobil, bahkan kantongan (walkman). Karena harga yang cenderung terjangkau oleh seluruh lapisan masyarakat, ketersediaannya dapat diandalkan, 2. Rekaman dapat digandakan untuk keperluan perorangan sehingga pesan dan isi pelajaran dapat berada dibeberapa tempat pada waktu yang bersamaan, 3. Merekam peristiwa atau isi pelajaran untuk digunakan kemudian, atau merekam pekerjaan siswa sendiri dapat dilakukan dengan media audio, 4. Rekaman memberikan kesempatan kepada siswa untuk mendengarkan diri sediri sebagai alat diagnosis guna membantu meningkatkan keterampilan mengucapkan, membaca, mengaji atau berpidato, dan pengoperasian radio tape/tape recorder relatif mudah.

Model Pembelajaran Think Talk Write adalah model pembelajaran yang menumbuhkan proses berfikir siswa, menanya dan menulis hasil tersebut dari proses diskusi. Jadi Model pembelajaran Think Talk Write berbantuan media Tape Recorder adalah proses pembelajaran yang dapat meningkatkan daya ingat dan membuat siswa lebih bersemangat dalam mengikuti proses pembelajaran di kelas berjalan dengan baik sehingga tujuan pembelajaran dapat tercapai dengan baik dan meningkatkan keterampilan berbicara siswa.

Berdasarkan pemaparan diatas, diduga terdapat perbedaan keterampilan berbicara siswa yang menggunakan model pembelajaran Think Talk Write dengan siswa yang tidak menggunakan model pembelajaran Think Talk Write. Oleh karena itu, diperlukan melakukan kajian tentang model pembelajaran yang paling efektif dalam upaya untuk meningkatkan keterampilan berbicara siswa, sehingga difokuskan penelitian yang berjudul Pengaruh Model Pembelajaran Think Talk Write Berbantuan Media Tape Recorder Terhadap Keterampilan Berbicara Kelas IV SD Gugus III Kecamatan Tabanan.

\section{Metode}

Penelitian ini merupakan penelitian eksperimen semu (quasi eksperiment). Karena tidak semua variabel yang muncul dan kondisi eksperimen dapat diatur dan dikontrol secara ketat. Penelitian ini menggunakan rancangan non equivalent post-test only control group design. Secara prosedur desain penelitian ini disajikan dalam gambar dibawah ini.

\begin{tabular}{|lll|}
\hline Kelas & Perlakuan & Post-test \\
Eksperimen & $\mathrm{X}_{1}$ & $\mathrm{O}_{1}$ \\
Kontrol & $\mathrm{X}_{2}$ & $\mathrm{O}_{2}$ \\
\hline
\end{tabular}

\section{Gambar01 Rancangan Non-equivalent Post test only control grup design} (Sumber : Agung,2014:163)

Keterangan:

$\mathrm{X}_{1} \quad$ : Perlakuan pada kelompok eksperimen.

$\mathrm{X}_{2} \quad$ : Dibelajarkan secara konvensional pada kelompok kontrol.

$\mathrm{O}_{1} \quad$ : Menyatakan pengamatan akhir (post-test) pada kelompok eksperimen.

$\mathrm{O}_{2} \quad$ : Menyatakan pengamatan akhir (post-test) pada kelompok kontrol.

Dalam menerapkan model pembelajaran Think Talk Write diberikan untuk kelas eksperimen, sedangkan untuk kelompok kontrol pembelajaran secara konvensional. Dalam penelitian ini penyetaraan menggunakan nilai ulangan harian Bahasa Indonesia, setelah itu untuk nilai Post test dianalisis sebagai data penelitian.

Populasi dalam penelitian ini adalah seluruh siswa kelas IV SD Gugus III Kecamatan Tabanan, yang terdiri dari 4 kelas. Jumlah populasi dari penelitian ini adalah 119 siswa. 
Teknik pengambilan sampel pada penelitian ini adalah Random Sampling. Dimana pada saat pengambilan sampel yang di random adalah kelasnya, sehingga semua kelas mendapatkan peluang yang sama untuk menjadi sampel penelitian.

Pengambilan sampel dilakukan dengan cara undian. Dalam penelitian ini, setiap kelas memiliki hak yang sama dan mendapatkan kesempatan dipilih menjadi sampel yang dilakukan dengan cara dua kali pengundian. Cara yang digunakan dengan cara menulis nomor pada semua nama kelas IV di seluruh SD populasi pada masing-masing kertas yang jumlahnya 4 kelas, kemudian kertas digulung. Lalu gulungan kertas dimasukkan ke dalam botol lalu dikocok. Tahap pertama pengundian untuk memilih dua kelas yang akan dijadikan sampel penelitian.

Setelah itu, dilakukan uji prasyarat untuk memenuhi syarat melakukan penelitian dengan menggunakan uji kesetaraan menggunakan anava A. Setelah sampel setara, pengundian kedua dilakukan untuk memilih kelas yang akan dijadikan kelas eksperimen dan kelas kontrol.

Data yang dikumpulkan dalam penelitian ini adalah data tentang keterampilan berbicara kelas IV SD Gugus III Kecamatan Tabanan, Tahun Ajaran 2018/2019. Metode yang digunakan dalam penelitian ini adalah metode nontes. Nontes keterampilan berbicara ini dibuat berupa rubrik penilaian dalam bentuk lembar observasi.

Metode analisis data yang digunakan dalam penelitian ini yaitu analisis statistic inferensial. Karena untuk mencari perbedaan, maka analisis inferensial yang digunakan dalam penelitian ini adalan uji-t ( $t$-test). Untuk dapat menggunakan teknik analisis tersebut dibutuhkan data yang berdistribusi normal dan homogen. Maka perlu dilakukan uji normalitas data dan uji homogenitas untuk memenuhi prasyarat yang dibutuhkan untuk menggunakan teknik analisis $\mathrm{Uji}-\mathrm{t}(\mathrm{t}$-test).

\section{Hasil dan Pembahasan}

Deskripsi data hasil penelitian ini memaparkan mengenai perolehan hasil post test pada kelompok eksperimen dan kelompok kontrol di SD Gugus III Kecamatan Tabanan Tahun Ajaran 2018/2019. Data yang diperoleh dalam penelitian ini dikelompokkan menjadi dua yaitu data keterampilan berbicara bahasa Indonesia siswa kelompok eksperimen di SD Negeri 1 Denbantas dan data keterampilan bahasa Indonesia di SD Negeri 4 Dauh Peken.

Dari data lembar penilaian observasi keterampilan berbicara dengan 4 keterampilan yang dilakukan setelah 6 kali perlakuan. Banyaknya siswa pada kelompok eksperimen adalah 32 dan kelompok kontrol adalah 30 siswa. Data nilai rata-rata (M), Varian (S) dan standar deviasi (SD) disajikan dalam tabel 01.

Tabel 01. Tabel Nilai Rata-Rata, Varian, dan Standar Deviasi Keterampilan Berbicara Kelas IV di SD Gugus 3 Kecamatan Tabanan

\begin{tabular}{lcccc}
\hline $\begin{array}{l}\text { Model } \\
\text { Pembelajaran }\end{array}$ & $\begin{array}{c}\text { Jumlah siswa tiap } \\
\text { kelompok }\end{array}$ & Nilai Rata-rata & Varian & Standar Deviasi \\
\hline $\begin{array}{l}\text { Kelompok } \\
\begin{array}{l}\text { Eksperimen } \\
\text { Kelompok }\end{array}\end{array}$ & 32 & 88,28 & 74,97 & 8,66 \\
Kontrol & 30 & 69,17 & 80,64 & 8,98 \\
\hline
\end{tabular}

Berdasarkan tabel 1 Nilai rata-rata keterampilan berbicara kelompok siswa yang dibelajarkan melalui model pembelajaran think talk write berbantuan media tape recorder untuk kelompok eksperimenadalah $X=88,28$ dengan varian sebesar $S^{2}=74,97$ dan standar deviasi $S$ $=8,66$. Sedangkan nilai rata-rata keterampilan berbicara kelompok siswa yang dibelajarkan secara konvensional untuk kelompok kontrol adalah $X=69,17$ dengan varian $S^{2}=80,64$ dan standar deviasi $S=8,98$.

Uji normalitas sebaran dilakukan untuk menyajikan bahwa sampel benar-benar berasal dari populasi yang berdistribusi normal, sebab jika data tidak berdistribusi normal maka pengujian tidak dapat dilakukan dengan uji-t. Untuk uji normalitas data digunakan uji ChiSquare $\left(x^{2}\right)$ pada taraf sifnifikasi $5 \%$ dan derajat kebebasan $\mathrm{dk}=(\mathrm{k}-2-1)$. Langkah-langkah uji Chi-Square $\left(x^{2}\right)$ kelompok eksperimen dapat disajikan pada tabel berikut. 
Tabel 02. Tabel Rekapitulasi Hasil Uji Normalitas Sebaran Data Kelompok Eksperimen

\begin{tabular}{cccccc}
\hline Rentangan & fh(\%) & Fo & fo - fh & (fo-fh) & $\frac{(f o-f h)^{2}}{f h}$ \\
\hline $62-70$ & 0,72 & 0 & 0,7 & 0,52 & 0,72 \\
$71-79$ & 4,34 & 5 & 0,7 & 0,02 & 0,00 \\
$80-88$ & 10,92 & 12 & 1,1 & 1,17 & 0,11 \\
$89-96$ & 10,92 & 11 & 0,1 & 0,01 & 0,00 \\
$97-105$ & 4,34 & 4 & 0,3 & 0,12 & 0,03 \\
$106-113$ & 0,72 & 0 & 0,7 & 0,52 & 0,72 \\
\hline$\Sigma$ & & 32 & & 3,13 \\
\hline
\end{tabular}

Hasil $x^{2}$ selanjutnya di konsultasikan ke tabel chi-square pada taraf signifikansi $5 \%$. Berdasarkan tabel chi-square pada taraf signifikansi $5 \%$ dengan $\mathrm{dk}=$ jumlah baris $-1=6-1=$ 5 , di dapat harga chi-square sebesar 11,07 dan chi-square hitung sebesar 3,13 sehingga dapat diketahui bahwa $x^{2}$ hitung $<x^{2}$ tabel $(11,07)$ maka dapat disimpulkan bahwa data keterampilan berbicara bahasa Indonesia kelompok eksperimen berdistribusi normal.

Tabel 03. Tabel Rekapitulasi Hasil Uji Normalitas Sebaran Data Kelompok Kontrol

\begin{tabular}{cccccc}
\hline Rentangan & fh(\%) & Fo & fo-fh & (fo-fh) $)^{2}$ & $\frac{(f o-f h)^{2}}{f h}$ \\
\hline $42-51$ & 0,68 & 0 & 0,68 & 0,46 & 0.68 \\
$52-60$ & 4,07 & 4 & 0,07 & 0,00 & 0.00 \\
$61-69$ & 10,23 & 15 & 4,77 & 22,75 & 2.22 \\
$70-78$ & 10,23 & 6 & 4,23 & 17,89 & 1.75 \\
$79-87$ & 4,07 & 4 & 0,07 & 0,00 & 0.00 \\
$88-96$ & 0,68 & 1 & 0,32 & 0,10 & 0.15 \\
\hline$\Sigma$ & & & & \\
\hline
\end{tabular}

Hasil $x^{2}$ selanjutnya di konsultasikan ke tabel chi-square pada taraf signifikansi $5 \%$. Berdasarkan tabel chi-square pada taraf signifikansi $5 \%$ dengan $\mathrm{dk}=$ jumlah baris $-1=6-1=$ 5, di dapat harga chi-square sebesar 11,07 dan chi-square hitung sebesar 7,50 sehingga dapat diketahui bahwa $\mathrm{x}^{2}{ }_{\text {hitung }}<\mathrm{x}_{\text {tabel }}^{2}(11,07)$ maka dapat disimpulkan bahwa data hasil belajar bahasa Indonesia kelompok kontrol berdistribusi normal.

Uji homogenitas varians antar kelompok bertujuan untuk memeriksa kesamaan varians antar kelompok perlakuan. Dalam penelitian ini, uji homogenitas dilakukan terhadap varians pasangan antar kelompok eksperimen dan kontrol. Uji yang digunakan adalah uji-F dengan kriteria data homogen jika $F_{\text {hit }}<F_{\text {tab. }}$. Rekapitulasi hasil uji homogenitas varians antar kelompok eksperimen dan kontrol disajikan pada tabel 4 di bawah ini.

Berdasarkan hasil analisis, diketahui $F_{\text {hitung }}$ hasil kelompok eksperimen dan kontrol adalah 1,08 sedangkan $F_{\text {tabel }}$ pada $\mathrm{db}_{\text {pembilang }}=31, \mathrm{db}_{\text {penyebut }}=29$, dan taraf signifikansi $5 \%$ adalah 1,94 . Sehingga varians data kelompok eksperimen dan kontrol memiliki varians yang homogen. Berdasarkan hasil uji prasyarat yang terdiri dari uji normalitas dan homogenitas varians, dapat disimpulkan bahwa kedua kelompok sampel berdistribusi normal dan memiliki varians yang homogen. Dengan demikian, uji hipotesis menggunakan uji-t dapat dilakukan.

Selanjutnya dilakukan uji hipotesis statistik yaitu uji-t. Uji-t digunakan untuk menguji hipotesis nol $\left(H_{0}\right)$ dengan taraf signifikansi $5 \%$. Karena jumlah sampel sama $\left(\mathrm{n}_{1}=\mathrm{n}_{2}\right)$ maka $t$-test yang digunakan rumus polled varians.

Berdasarkan hasil analisis uji-t dari nilai postest keterampilan berbicara siswa diperoleh hasil sebagai berikut. 
Tabel 04 Tabel Hasil Analisis Uji-T

\begin{tabular}{|c|c|c|c|c|c|}
\hline Kelompok & $\mathbf{N}$ & Db & Mean & $t_{\text {hit }}$ & $t_{\text {tab }}$ \\
\hline Eksperimen & 32 & \multirow[b]{2}{*}{60} & 88,28 & \multirow[b]{2}{*}{8,532} & \multirow[b]{2}{*}{2,000} \\
\hline Kontrol & 30 & & 69,17 & & \\
\hline
\end{tabular}

Setelah menganalisis data post test yang diperoleh nilai rata-rata keterampilan berbicara pada kedua kelompok yaitu pada kelompok eksperimen 88,28 dan pada kelompok kontrol 69,17 . Dari hasil perhitungan bahwa nilai rata-rata dikelompok eksperimen lebih tinggi dari di kelompok kontrol.

Berdasarkan uji hipotesis diperoleh $t_{\text {hitung }}=8,532$ sedangkan pada taraf signifikansi $5 \%$ dan $\mathrm{dk}=60$ diperoleh harga $\mathrm{t}_{\text {tabel }}=2,000$. Dengan demikian, $\mathrm{t}_{\text {hitung }}=8,532>\mathrm{t}_{\text {tabel }}=2,000$ sehingga $\mathrm{H}_{0}$ ditolak dan $\mathrm{H}_{1}$ diterima. Ini berarti terdapat pengaruh model pembelajaran Think Talk Write Berbantuan Media Tape Recorder terhadap Keterampilan Berbicara Kelas IV SD Gugus III Kecamatan Tabanan Tahun Ajaran 2018/2019. Melalui hasil analisis data, diperoleh nilai rata-rata kelompok eksperimen $\bar{X}=88,28$ dan kelompok kontrol $\bar{X}=69,17$. Ini menunjukkan bahwa nilai rata-rata kelompk eksperimen $\bar{X}=88,28>\bar{X}=69,17$ dari kelompok kontrol.

Hal ini disebabkan karena model pembelajaran Think Talk Write dengan pengembangan tape recorder yang menggantikan phonograph dan recording optical, karena lebih mudah dan biayanya yang lebih terjangkau. Tape mulai populer tahun 1950-an. Perkembangan tape recorder ini membawa perubahan yang pesat dalam membuat musik. Karena dengan proses menjadi lebih mudah, pemberian efek fade in dan fade out bisa dilakukan. Jika sebelumnya seorang yang akan direkam harus mengucapkan suara atau membawakan lagu dengan sempurna saat direkam, dengan adanya tape recorder, proses penambahan akan lebih mudah, berbagai kesalahan dapat diperbaiki dengan mudah.

Hal ini berbeda dengan siswa yang dibelajarkan dengan konvensional pada kelas kontrol. Pembelajaran mencirikan pembelajaran yang berpusat pada guru. Secara teoritis, pembelajaran yang menggunakan model konvensional adalah pembelajaran tradisional atau disebut juga dengan metode ceramah, karena sejak dulu metode ini telah dipergunakan sebagai alat komunikasi lisan antara guru dengan anak didik dalam proses belajar dan mengajar. Dalam hal ini, terlihat bahwa pembelajaran kurang maksimal dalam meningkatkan hasil belajar siswa.

Dengan demikian hasil penelitian ini membuktikan bahwa model pembelajaran Think Talk Write dengan pengembangan tape recorder memberikan pengaruh terhadap keterampilan berbicara siswa. Tentu saja dalam hal ini hasil belajar siswa meningkat. Hal ini dapat dilihat dari pembelajaran lebih banyak menekankan siswa aktif di dalam kelompoknya sedangkan guru hanya bertugas sebagai fasilitator dan motivator dalam pembelajaran.

Hambatan yang ditemukan ketika dilakukan penelitian pada kelas eksperimen tidak terlalu berarti. Hanya ada beberapa hambatan kecil seperti masih terdapat beberapa siswa yang suka bercanda, guru harus memberikan perhatian lebih kepada siswa yang maju kedepan dan kurang fokus dalam mengikuti proses pembelajaran tetapi hal tersebut sudah dapat ditanggulangi oleh guru dengan memberikan perhatian lebih kepada siswa yang bersangkutan. Sementara hambatan di kelas kontrol lebih banyak ditemukan. Hambatan-hambatan tersebut adalah banyak ditemukan siswa yang kurang memperhatikan guru saat menjelaskan materi seperti siswa bermain-main di kelas. Selain itu terdapat pula beberapa siswa yang bercanda pada saat proses pembelajaran berlangsung. Dan siswa suka mengobrol dengan teman sebangku pada saat guru menjelaskan sehingga siswa menjadi tidak fokus dalam mengikuti pembelajaran.

\section{Simpulan dan Saran}

Berdasarkan hasil penelitian dan pembahasan, dapat disimpulkan bahwa terdapat pengaruh yang signifikan kelompok siswa yang dibelajarkan menggunakan model pembelajaran Think Talk Write berbantuan media Tape Recorder terhadap Keterampilan Berbicara kelas IV di SD Gugus III Kecamatan Tabanan Tahun Ajaran 2018/2019. Ini diperkuat oleh hasil uji hipotesis menggunakan uji-t. Berdasarkan hasil analisis dengan menggunakan uji- 
$t$ dengan $d k=n 1+n 2-2=60$ pada taraf signifikansi $5 \%$ diperoleh $t_{\text {hitung }}=8,532>t_{\text {tabel }}=2,000$ sehingga $\mathrm{H}_{0}$ ditolak. Hal ini berarti terdapat perbedaan yang signifikan keterampilan berbicara antara kelompok siswa yang dibelajarkan menggunakan model pembelajaran think talk write berbantuan media tape recorder dan kelompok siswa yang dibelajarkan menggunakan pembelajaran konvensional. Hasil penelitian menunjukkan nilai rata-rata kelompok eksperimen lebih dari kelompok kontrol $(\bar{x}=88,28>\bar{x}=69,17)$. Jadi dapat disimpulkan bahwa terdapat pengaruh model pembelajaran think talk write berbantuan media tape recorder terhadap keterampilan berbicara kelas IV SD Gugus III Kecamatan Tabanan tahun ajaran 2018/2019.

Ada beberapa saran yang dapat diajukan berdasarkan temuam dan kajian penelitian ini adalah sebagai berikut. 1) Kepada Siswa. Sebagai wahana membelajarkan diri siswa untuk berbagi antar siswa yang satu dengan yang lain dan menyadarkan siswa bahwa belajar merupakan proses bukan berorientasi pada nilai saja. 2) Kepada Guru, disarankan agar lebih kreatif untuk memberikan fasilitas berupa sumber belajar dan kesempatan yang lebih besar bagi siswa pada pembelajaran dengan menggunakan model pembelajaran Circuit Learning berbantuan media flipchart sehingga tercipta pembelajaran yang lebih aktif dan menyenangkan bagi siswa. 3) Kepada Kepala Sekolah, disarankan agar dapat menggunakan hasil penelitian ini sebagai pendukung sumber belajar guru dalam meningkatkan kualitas pembelajaran di sekolah sehingga sekolah mampu menghasilkan siswa yang memiliki output berkualitas. Dan 4) Kepada Peneliti Lain, disarankan agar hasil penelitian ini digunakan sebagai referensi untuk melaksanakan penelitian selanjutnya atau menemukan inovasi kegiatan pembelajaran lainnya yang bermakna dan menyenangkan bagi siswa.

\section{Daftar Pustaka}

Agung, Anak Gede Agung. 2014. Buku Ajar Metodologi Penelitian Pendidikan. Malang: Aditya Media Publishing.

Agung, Anak Gede Agung. 2015. Statistik Dasar Untuk Pendidikan. Singaraja: Universitas Pendidikan Ganesha

Amirono. 2016. Evaluasi dan Penilaian Pembelajaran Kurikulum 2013. Yogyakarta: Gava Media.

Kosasih. 2014. Strategi Belajar dan Pembelajaran Implementasi Kurikulum 2013. Jakarta: Universitas Terbuka.

Koyan, I Wayan. 2012. Statistik Pendidikan Teknik Analisis Data Kuantitatif. Singaraja: Universitas Pendidikan Ganesha.

Setyosari, Punaji. 2015. Metode Penelitian Pendidikan dan Pengembangan. Jakarta: PRENADAMEDIA GROUP.

Shoimin, Aris. 2014. 68 Model Pembelajaran Inovatif dalam Kurikulum 2013. Yogyakarta: ARRUSS MEDIA.

Solchan. 2017. Pendidikan Bahasa Indonesia di SD. Banten: Universitas Terbuka.

Sugiono. 2017. Statistik Untuk Penelitian. Bandung: Alfabeta. 